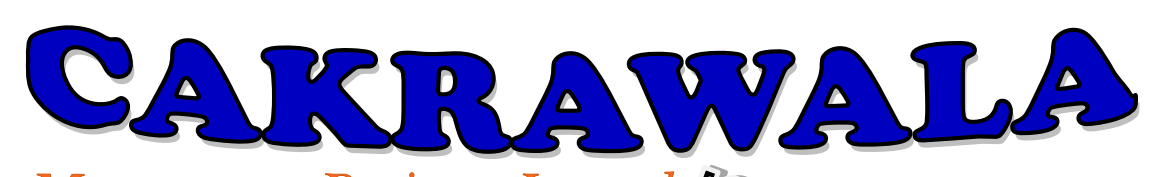

Management Business Journal [CM]-B]J/olume 2 Nomor 2 November Tahun 2019

\title{
PENGARUH AUDIT KINERJA SEKTOR PUBLIK DAN PENGAWASAN FUNGSIONAL TERHADAP AKUNTABILITAS PUBLIK PADA DINAS PENDIDIKAN di JAKARTA PUSAT
}

\author{
Hermawati \\ Universitas Gunadarma \\ Correspondence email: Hermawati87@ymail.com
}

Page | - $322-$

\begin{abstract}
ABSTRAK
Penelitian ini untuk menganalisis pengaruh audit kinerja dan pengawasan fungsional terhadap akuntabilitas publik pada Suku Dinas Pendidikan Kota Jakarta Pusat.

Sampel penelitian ini berjumlah 54 responden. Teknik analisis data menggunakan analisis deskriptif, analisis regresi linier berganda, uji hipotesis dengan uji t dan uji F.

Uji hipotesis secara parsial bahwa audit kinerja berpengaruh positif dan signifikan terhadap akuntabilitas publik. pengawasan fungsional berpengaruh positif dan signifikan terhadap akuntabilitas publik. Secara simultan audit kinerja dan pengawasan fungsional berpengaruh positif dan signifikan terhadap akuntabilitas publik. Besarnya pengaruh audit kinerja sektor publik dan pengawasan fungsional terhadap akuntabilitas publik adalah sebesar $55,4 \%$. Untuk akuntabilitas publik agar dapat terlaksana dengan baik, maka harus lebih terbuka dalam hal laporan pertanggungjawaban program-program yang terlaksana kepada masyarakat yaitu melalui perwakilan publik. Selain itu masukan dan keluhan yang berasal dari masyarakat dapat menjadi feedback dalam perbaikan kinerja pada periode berikutnya.
\end{abstract}

\section{ABSTRACT}

This research is to analyze the effect of performance audit and functional supervision on public accountability in Central Jakarta City Education Office.

The sample of this study was 54 respondents. Data analysis techniques using descriptive analysis, multiple linear regression analysis, hypothesis testing with $t$ test and $F$ test.

Partial hypothesis test that performance audit has positive and significant effect on public accountability. functional supervision has a positive and significant effect on public accountability. Simultaneously performance audit and functional supervision have positive and significant effect on public accountability. The magnitude of the effect of public sector performance audits and functional oversight on public accountability is $55.4 \%$. For public accountability to be carried out properly, it must be more open in terms of the accountability reports of programs implemented to the public, through public representatives. In addition, input and complaints from the community can be feedback in improving performance in the next period.

Keywords : Audit, Performance, Functional, Accountability, Public. 


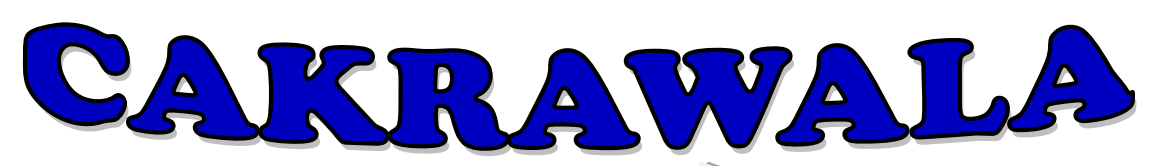

\section{Management Business Journal [CM:-B] J]/olume 2 Nomor 2 November Tahun 2019}

\section{PENDAHULUAN}

Perubahan pada sistem pemerintahan dari sentralisasi ke desentralisasi mendorong perlunya perbaikan dalam pengelolaan dan pertanggungjawaban, maka dalam era otonomi daerah sekarang ini daerah diberikan kewenangan mengurus dan mengatur semua urusan pemerintahan di luar urusan pemerintah pusat, pemberian otonomi daerah ini diharapkan dapat meningkatkan efisiensi, efektivitas, dan akuntabilitas sektor publik di Indonesia. Penyelenggaraan otonomi daerah harus selalu berorientasi pada peningkatan kesejahteraan masyarakat dengan selalu memerhatikan kepentingan-kepentingan dan aspirasi yang tumbuh dalam masyarakat. Untuk itu, otonomi daerah diharapkan dapat menciptakan efisiensi dan efektivitas pengelolaan sumber daya daerah, meningkatkan kualitas pelayanan umum dan kesejahteraan masyarakat, membudayakan dan menciptakan ruang bagi masyarakat untuk ikut berpartisipasi dalam proses pembangunan.

Oleh karena itu, kepercayaan yang diberikan oleh masyarakat kepada penyelenggara pemerintahan haruslah diimbangi dengan adanya pemerintahan yang baik. Dalam upaya menuju pada pemerintahan yang baik atau good governance ditandai dengan tiga pilar utama yang merupakan elemen dasar yang saling berkaitan. Ketiga elemen dasar tersebut adalah partisipasi, transparansi dan akuntabilitas. Suatu pemerintahan yang baik harus membuka pintu yang seluasluasnya agar semua pihak yang terkait dalam pemerintahan tersebut dapat berperan serta atau berpartisipasi secara aktif, jalannya pemerintahan harus diselenggarakan secara transparan dan pelaksanaan pemerintahan tersebut harus dapat dipertanggungjawabkan. Dalam bahasa akuntansi, akuntabilitas (kemampuan memberikan pertanggungjawaban) merupakan dasar dari pelaporan keuangan. Fenomena yang dapat diamati dalam perkembangan sektor publik dewasa ini adalah semakin menguatnya tuntutan pelaksanaan akuntabilitas publik oleh organisasi sektor publik, seperti pemerintah pusat dan daerah, unit-unit kerja pemerintah, departemen dan lembagalembaga negara.

Tekanan terhadap organisasi sektor publik, khususnya organisasi pemerintah baik pusat dan daerah serta perusahaan milik pemerintah dan organisasi sektor publik lainnya untuk memperbaiki kinerjanya mendorong perlunya audit kinerja sektor publik. Akuntabilitas dan transparansi dalam pengelolaan keuangan pemerintah pusat maupun daerah sebagai organisasi sektor publik merupakan tujuan penting dari reformasi akuntansi dan administrasi sektor publik. Untuk dapat memastikan bahwa pengelolaan keuangan pemerintah yang telah dilakukan aparatur pemerintah, maka fungsi akuntabilitas dan audit atas pelaporan keuangan sektor publik harus berjalan dengan baik. Seiring dengan tuntutan masyarakat agar organisasi sektor publik meningkatkan kualitas, profesionalisme dan akuntabilitas publik dalam menjalankan aktivitasnya, diperlukan audit yang tidak hanya terbatas pada keuangan dan kepatuhan saja, tetapi perlu diperluas dengan melakukan audit terhadap kinerja sektor publik.

Audit Kinerja menurut UU No.15 Tahun 2004 tentang Pemeriksaan Pengelolaan dan Tanggung Jawab Keuangan Negara Pasal 4 (3) yaitu pemeriksaan kinerja adalah pemeriksaan atas pengelolaan keuangan negara yang terdiri atas pemeriksaan aspek ekonomi dan efisiensi serta pemeriksaan aspek efektivitas. Audit kinerja memfokuskan pemeriksaan pada tindakan-tindakan dan kejadiankejadian ekonomi yang menggambarkan kinerja entitas atau fungsi yang diaudit. Audit kinerja 


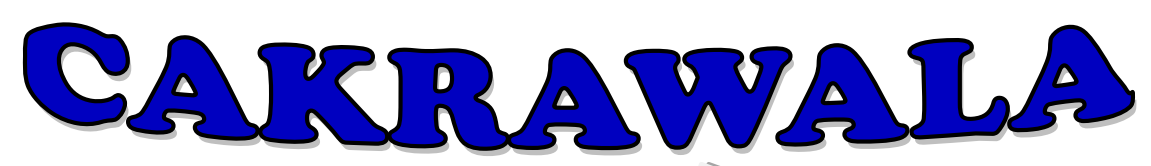

\section{Management Business Journal [CM:-B]J/lolume 2 Nomor 2 November Tahun 2019}

meliputi audit atas aspek ekonomi, efisiensi, dan efektivitas yang pada dasarnya merupakan perluasan dari audit keuangan dalam hal tujuan dan prosedurnya, yang membedakan antara audit kinerja dengan audit lainnya adalah dalam hal laporan audit. Dalam audit keuangan, hasil audit adalah berupa pendapat (opini) auditor secara independen dan obyektif tentang kewajaran laporan keuangan sesuai dengan kriteria standar yang ditetapkan tanpa pemberian rekomendasi perbaikan. Sedangkan dalam audit kinerja, audit tidak hanya sekedar menyampaikan kesimpulan berdasarkan tahapan audit yang telah dilaksanakan akan tetapi dilengkapi dengan rekomendasi untuk perbaikan di masa mendatang. (Supardi dan wiarty, 2010).

Selain itu, pengawasan secara intern di masing-masing satuan kerja dilakukan oleh atasan langsung dan oleh Badan Pengawas Daerah dengan melakukan pemeriksaan reguler. Dari hasil pemeriksaan yang dilakukan oleh BPK RI mengungkapkan bahwa pada umumnya pengawasan atasan langsung masih lemah, sehingga masih ditemukan penyimpangan-penyimpangan dalam pelaksanaan pengendalian intern dan kepatuhan terhadap peraturan perundang-undangan yang disebabkan oleh lemahnya pengawasan atasan langsung. Dari hal tersebut fenomena yang dapat kita pahami bahwa masih lemahnya pengawasan pada masing-masing satuan kerja, hal ini dapat menimbulkan berbagai macam bentuk penyimpangan dari pelaksanaan anggaran.

\section{Audit Kinerja Sektor Publik}

Menurut Suratmi dkk (2014:2) menyatakan bahwa audit kinerja sektor publik menitikberatkan pemeriksaan pada tindakan-tindakan dan kejadian-kejadian ekonomi yang menggambarkan kinerja entitas atau fungsi yang diaudit. Dimana audit kinerja meliputi audit atas aspek ekonomi, efisiensi, dan efektivitas yang merupakan perluasan dari audit atas laporan keuangan dari segi tujuan dan prosedur dalam pelaksanaannya.

Audit kinerja adalah perencanaan, pengumpulan dan pengevaluasian bukti-bukti yang cukup, relevan, material dan kompeten, yang dilakukan oleh pemeriksaan yang bebas dengan sasaran untuk menilai apakah dalam pencapaian tujuannya telah menggunakan sumber-sumber secara ekonomis, efisien dan efektif, yang menghasilkan kesimpulan, merumuskan saran-saran perbaikan serta melaporkan hasilnya pada pihak ketiga (Setyawan dalam Arfianto, 2010:17). Sedangkan menurut Ulum (dalam Arfianto, 2010:18) audit kinerja adalah pengujian sistematis, terorganisasi dan obyektif atas suatu entitas untuk menilai pemanfaatan sumber daya dalam memberikan pelayanan publik secara efisien dan efektif dalam memenuhi harapan stakeholder dan memberikan rekomendasi guna peningkatan kinerja. Selanjutnya, pengertian Audit Kinerja menurut UU No.15 Tahun 2004 tentang Pemeriksaan Pengelolaan dan Tanggung Jawab Keuangan Negara Pasal 4 ayat 3 adalah : "Pemeriksaan Kinerja adalah pemeriksaan dan pengelolaan keuangan negara yang terdiri atas pemeriksaan aspek ekonomi dan efisiensi serta pemeriksaan aspek efektivitas."

PP No. 60 Tahun 2008 tentang SPIP Pasal 50 ayat (2) menyatakan bahwa audit kinerja adalah audit atas pengelolaan keuangan negara dan pelaksanaan tugas dan fungsi Instansi Pemerintah yang terdiri atas aspek kehematan, efisiensi dan efektifitas.

Penggunaan istilah-istilah berbeda untuk hal yang sama seringkali menimbulkan perdebatan apakah istilah-istilah tersebut merujuk pada pengertian yang sama. Istilah pemeriksaan seringkali 


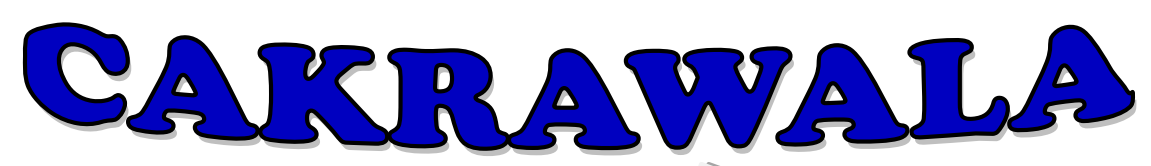

\section{Management Business Journal [CM]-BJ]/olume 2 Nomor 2 November Tahun 2019}

diidentikkan dengan istilah audit, seperti halnya istilah pemeriksaan dalam Undang-Undang Nomor 15 Tahun 2004 Pemeriksaan Pengelolaan dan Tanggung Jawab Keuangan Negara. Berdasarkan berbagai definisi di atas, dapat disimpulkan bahwa tujuan dasar dari audit kinerja adalah menilai kinerja suatu organisasi, program, atau kegiatan yang meliputi atas aspek ekonomi, efisiensi, dan efektivitas.

\section{Indikator Audit Kinerja Sektor Publik}

Salah satu pendekatan untuk mengukur kinerja akuntabilitas publik adalah dengan pendekatan value for money, yaitu indikator yang memberikan informasi kepada kita apakah anggaran (dana) yang dibelanjakan menghasilkan suatu nilai tertentu bagi masyarakatnya. Dalam konsep ini, indikator yang dimaksud adalah ekonomi, efisien, dan efektif. Ketiga prinsip value for money yang meliputi ekonomi, efisien dan efektif menurut Nordiawan dan Hertianti (2010:160) tersebut lebih lanjut dapat dijelaskan sebagai berikut :

1. Ekonomi. Konsep ekonomi sangat terkait dengan konsep biaya untuk memperoleh unit input. Ekonomi berarti sumber daya input hendaknya diperoleh dengan harga lebih rendah (spending less), yaitu harga yang mendekati harga pasar. Untuk memahami aspek aspek ekonomi dengan lebih baik, diperlukan pemahaman tentang input itu sendiri. Input adalah semua jenis sumber daya masukan yang digunakan dalam suatu proses tertentu untuk menghasilkan output. Input tersebut dapat berupa tenaga kerja (tenaga, keahlian, dan ketrampilan), serta asset-aset seperti gedung, peralatan, dan sebagainya. Input dibagi dua yaitu input primer dan input sekunder. Input primer adalah kas, sedangkan input sekunder adalah bahan baku, orang, infrastruktur, dan masukan lainnya yang digunakan untuk proses menghasilkan output. Indikator ekonomi merupakan indikator tentang penggunaan input. Dalam konteks dua jenis input yaitu input primer dan input sekunder

2. Efisiensi. Efisiensi adalah hubungan antara barang dan jasa (output) yang dihasilkan sebuah kegiatan/aktivitas dengan sumber daya (input) yang digunakan. Suatu organisasi, program, atau kegiatan dikatakan efisien apabila mampu menghasilkan output tertentu dengan input serendah-rendahnya, atau dengan input tertentu mampu menghasilkan output sebesarbesarnya (spending well). Organisasi sektor publik dinilai semakin efisien apabila rasio efisiensi cenderung di atas satu. Semakin besar rasio, maka semakin tinggi tingkat efisiensinya. Efisiensi harus dibandingkan dengan angka acuan tertentu, seperti efisiensi periode sebelumnya atau efisiensi di organisasi sektor publik lainnya. Apabila hasil rasionya lebih besar dibandingkan dengan hasil rasio program yang sama di unit kerja lain, maka program tersebut dapat dikatakan lebih efisien.

3. Efektivitas. Efektivitas menunjukkan kesuksesan atau kegagalan dalam pencapaian tujuan sebuah kegiatan/kebijakan di mana ukuran efektivitas merupakan refleksi output. Efektivitas terkait dengan hubungan antara hasil yang diharapkan dengan hasil yang sesungguhnya dicapai. Efektivitas merupakan hubungan antara output dengan tujuan. Semakin besar kontribusi output terhadap pencapaian tujuan, maka semakin efektif organisasi, program, atau kegiatan. Karena output yang dihasilkan organisasi sektor publik lebih banyak bersifat output tidak berwujud (intangible) yang tidak mudah dikuantifikasi, pengukuran efektivitas sering menghadapi kesulitan. Kesulitan dalam pengukuran efektivitas tersebut karena pencapaian hasil (outcome) sering tidak bisa diketahui dalam jangka pendek, tetapi dalam jangka panjang setelah program 


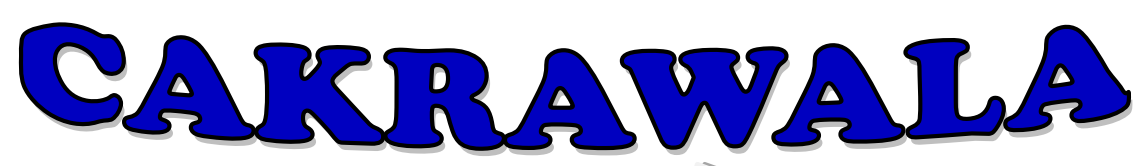

\section{Management Business Journal [CM]-BJ]/olume 2 Nomor 2 November Tahun 2019}

berakhir. Jadi, ukuran efektivitas biasanya dinyatakan secara kualitatif dalam bentuk pernyataan saja (judgement). Outcome sering kali dipengaruhi oleh hal-hal di luar kendali pemerintah, misalnya target jumlah panen padi di musim tertentu. Meskipun berbagai output yang mendukung hal tersebut telah dihasilkan, faktor cuaca terkadang lebih menentukan.

\section{Pengawasan Fungsional}

Pengawasan adalah suatu proses kegiatan penilaian terhadap objek pengawasan kegiatan tertentu dengan tujuan untuk memastikan apakah pelaksanaan tugas dan fungsi objek pengawasan dan atau kegiatan tersebut telah sesuai dengan yang telah ditetapkan. Sehingga dapat disimpulkan bahwa pengawasan bukan berupa pemeriksaan tetapi pengawasan yang lebih mengarah untuk menjamin pencapaian sasaran yang telah ditetapkan dalam peraturan daerah.

Adapun pengertian pengawasan fungsional berdasarkan Pasal 1 Peraturan Pemerintah No 20 tahun 2002 tentang pertimbangan dan pengawasan atas penyelenggara pemerintah daerah mengemukakan bahwa: "Pengawasan fungsional adalah pengawasan yang dilakukan oleh lembaga atau badan atau unit yang mempunyai tugas dan fungsi melakukan pengawasan melalui pemeriksaan, pengkajian, penyusutan dan penilaian".

Pengertian pengawasan fungsional menurut Halim (dalam Ardiansyah, 2010:25) menyatakan sebagai berikut : "Segala kegiatan dan bentuk tindakan untuk menjamin agar pelaksanaan suatu kegiatan berjalan dengan sesuai dengan rencana, aturan-aturan dan tujuan yang telah ditetapkan"

Pengertian pengawasan fungsional menurut Wasistiono (2010:142) adalah sebagai berikut : "Pengawasan yang dilakukan oleh aparat pengawasan fungsional, baik yang berasal dari lingkungan internal pemerintah daerah maupun yang berasal dari lingkungan eksternal pemerintah daerah."

Pengawasan atau penyelenggaraan pemerintah daerah menurut Peraturan Pemerintah No. 79 Tahun 2005 Pasal 1 tentang Pedoman Pembinaan dan Pengawasan Penyelenggaraan Pemerintahan Daerah menyatakan bahwa : "Pengawasan atas penyelenggaraan Pemerintahan Daerah adalah proses kegiatan yang ditujukan untuk menjamin agar Pemerintahan Daerah berjalan secara efisien dan efektif sesuai dengan rencana dan ketentuan peraturan perundang-undangan."

Indikator Pengawasan Fungsional

Berdasarkan Keputusan BPKP No. KEP-378/K/2004 tanggal 30 Mei 2004 Tentang Penetapan Berlakunya Standar Audit Aparat Pengawasan Fungsional Pemerintah. Ardiansyah (2010:29) standar audit pengawasan fungsional terbagi atas lima katogori yaitu :

1) Standar Umum
a) Keahlian
b) Independensi
c) Kecermatan profesi
d) Kerahasian

2) Standar Koordinasi dan Kendalian Mutu
a) Program kerja pengawasan
b) Koordinasi pengawasan
c) Kendali mutu

3) Standar Pelaksanaan 


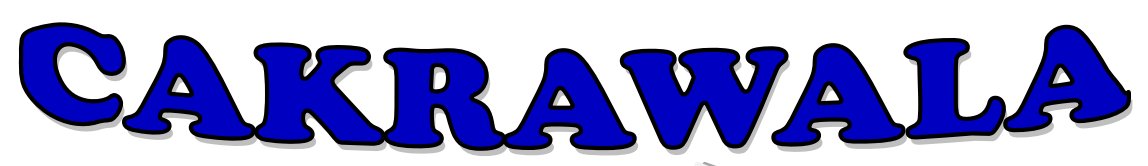

\section{Management Business Journal [CM:B, J]/olume 2 Nomor 2 November Tahun 2019}
a) Pelaksanaan dan supervisi
b) Pengendalian Internal
c) Bukti audit
d) Ketaatan peraturan perundang - undangan
e) Kertas kerja audit

4) Standar Pelaporan
a) Kesesuaian dengan prinsip akuntansi yang berlaku umum
b) Konsistensi
c) Pengungkapan yang memadai
d) Pernyataan pendapat
e) Laporan audit operasional
f) Kesesuaian dengan standar audit APFP
g) Tertulis dan segera
h) Distribusi laporan

5) Standar Tindak Lanjut
a) Kominikasi dengan auditan
b) Pemantauan tindak lanjut
c) Status temuan
d) Penyelesaian hukum

\section{Akuntabilitas Publik}

Menurut Renyowijoyo (2013:14) akuntabilitas publik adalah kewajiban pihak pemegang amanah (agent) untuk memberikan pertanggungjawaban, menyajikan, melaporkan dan mengungkapkan segala aktivitas dan kegiatan yang menjadi tanggung jawabnya kepada pihak pemberi amanah (principal) yang memiliki hak dan kewenangan untuk meminta pertanggungjawaban tersebut.

Sedangkan menurut Bastian (2010:385) mengemukakan Akuntabilitas Publik adalah: “ Akuntabilitas Publik adalah kewajiban agen untuk mengelola sumber daya, melaporkan, dan mengungkapkan segala aktivitas dan kegiatan yang berkaitan dengan penggunaan sumber daya publik kepada pihak pemberi mandat (principal)".

Berdasarkan teori diatas dapat dikatakan bahwa Akuntabilitas Publik merupakan bagian perwujudan kewajiban seseorang atau unit organisasi untuk mempertanggungjawabkan pengelolaan dan pengendalian sumber-sumber daya serta pelaksanaan kebijakan yang dipercayakan kepadanya dalam rangka mencapai sasaran atau tujuan yang telah ditetapkan dalam dokumen perencanaan melalui media pertanggungjawaban secara periodik.

organisasi sektor publik akuntabilitas memiliki beberapa aspek atau dimensi. Ellwod (dalam Renyowijoyo, 2013:14) menjelaskan bahwa terdapat empat aspek atau dimensi akuntabilitas yaitu,

1. Akuntabilitas Hukum adalah pertangungjawaban lembaga publik untuk berperilaku jujur dalam bekerja dan mentaati ketentuan hukum yang berlaku didalam penguanaan sumber dana publik. Sedangkan akuntabilitas kejujuran berkaitan dengan penghindaran penyalahgunaan jabatan, korupsi dan kolusi. Akuntabilitas hukum dan kejujuran pengukuranya dengan penggunaan dana sesuai anggaran dan ketaatan pada peraturan. 


\section{CAKrRAWALA}

\section{Management Business Journal [CM:-B] J]/lolume 2 Nomor 2 November Tahun 2019}

2. Akuntabilitas proses terkait dengan apakah prosedur yang digunakan dalam pertangungjawaban lembaga publik didalam melakukan pengelolaan organisasi secara efisien dan efektif dalam hal kecukupan efisiensi sistem informasi. Akuntabilitas proses dapat juga diartikan sebagai akuntabilitas kinerja karena untuk memeriksa terhadap kinerjanya apakah sesuai dengan yang diharapkan atau terjadi tindakan korupsi, kolusi dan nepotisme. Akuntabilitas proses ialah bahwa proses organisasi harus dapat dipertanggung jawabkan. dengan kata lain tidak terjadi inefisiensi dari ketidak efetifan organisasi.

3. Akuntabilitas program berkaitan dengan pertimbangan apakah tujuan yang ditetapkan dalam kegiatan yang dicapai atau tidaknya dan apakah telah mempertimbangkan alternatif program yang memberikan hasil yang optimal dengan biaya yang minimal. Lembaga-lembaga publik harus mempertanggungjawabkan program yang telah dibuat pada pelaksanaan program.

4. Akuntabilitas kebijakan menyangkut pertanggungjawaban pemerintah atau lembaga publik baik pusat maupun daerah atas kebijakan-kebijakan yang diambil pemerintah terhadap DPR/DPRD dan masyarakat luas. Dalam membuat kebijakan lembaga publik hendaknya dapat mempertanggungjawabkan kebijakan yang telah ditetapkan dengan mempertimbangkan dampak masa depan. Dalam membuat kebijakan harus dipertimbangkan apa tujuan kebijakan tersebut, mengapa kebijakan itu yang diambil,siapa sasaran dari kebijakan tersebut, stokeholder mana yang akan berpengaruh dan memperoleh dampak negatif dari kebijakan tersebut. Pengukuran akuntabilitas kebijakan dapat dilakukan dengan melihat kebijakan yang diambil atau diabaikan, dampak yang ditimbulkan terhadap kebijakan yang diambil atau diabaikan.

Adapun kerangka berpikir dalam penelitian ini, yaitu :

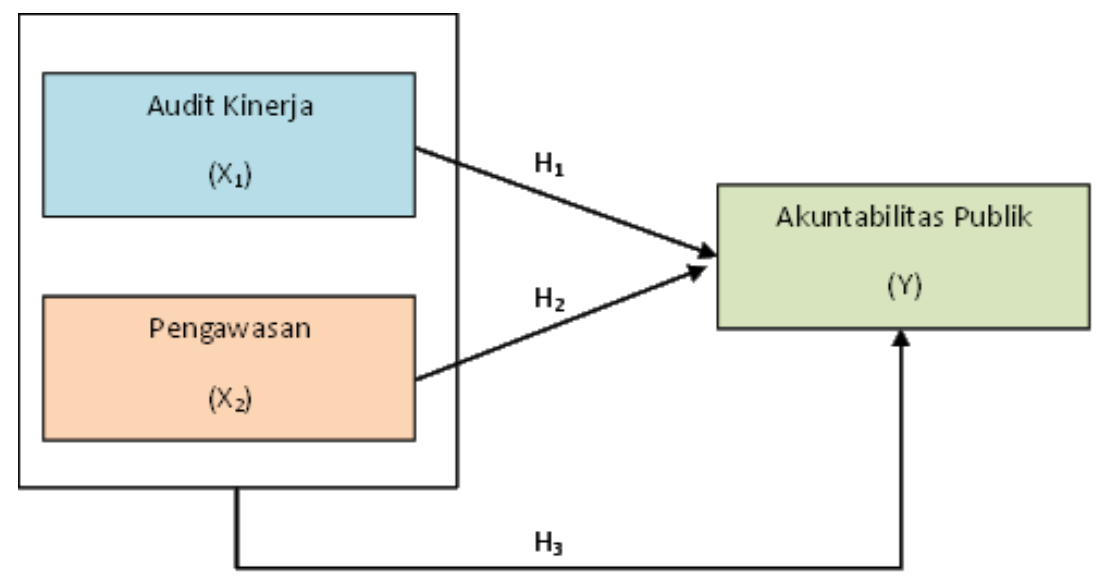

Gambar 1

Kerangka Pemikiran

Kerangka berpikir yang dimaksud adalah :

1. Pengaruh Audit Kinerja terhadap Akuntabilitas Publik. 


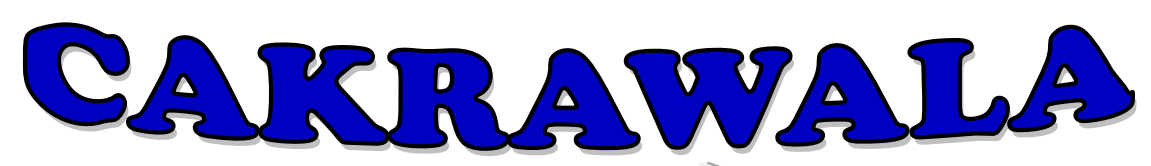

\section{Management Business Journal [CM]-BJ]/olume 2 Nomor 2 November Tahun 2019}

Menurut Rai (2010:31) menyatakan bahwa : “Audit kinerja adalah audit yang dilakukan secara objektif dan sistematis terhadap berbagai macam bukti untuk menilai kinerja entitas yang diaudit dalam hal ekonomi, efisiensi, dan efektivitas, dengan tujuan untuk memperbaiki kinerja dan entitas yang diaudit dan meningkatkan akuntabilitas publik."

Audit kinerja memfokuskan pemeriksaan pada tindakan-tindakan dan kejadian-kejadian ekonomi yang menggambarkan kinerja entitas atau fungsi yang diaudit. Audit kinerja merupakan suatu proses yang sistematis untuk memperoleh dan mengevaluasi bukti secara obyektif, agar dapat melakukan penilaian secara independen atas ekonomi dan efisiensi operasi, efektifitas dalam pencapaian hasil yang diinginkan dan kepatuhan terhadap kebijakan, peraturan dan hukum yang berlaku, menentukan kesesuaian antara kinerja yang telah dicapai dengan kriteria yang telah ditetapkan sebelumnya serta mengkomunikasikan hasilnya kepada pihak-pihak pengguna laporan tersebut.

Kemampuan mempertanggungjawabkan (akuntabilitas) dari sektor publik pemerintah sangat tergantung pada kualitas audit sektor publik. Tanpa kualitas audit yang baik, maka akan timbul permasalahan, seperti munculnya kecurangan, korupsi, kolusi dan berbagai ketidakberesan di pemerintahan. Kualitas audit sektor publik dipengaruhi oleh kapabilitas teknikal auditor serta independensi auditor baik secara pribadi maupun kelembagaan. Untuk meningkatkan sikap independensi auditor sektor publik, maka kedudukan auditor sektor publik harus terbebas dari pengaruh dan campur tangan serta terpisah dari pemerintah, baik secara pribadi maupun kelembagaan (Ritonga, 2013). Bastian (2007:48) menyatakan bahwa apabila pelaksanaan audit kinerja dilakukan dengan baik, maka tingkat akuntabilitas pemerintah dalam proses pengambilan keputusan oleh pihak yang bertanggungjawab akan meningkat, sehingga mendorong adanya pengawasan dan kemudian tindakan koreksi.

Penelitian Suratmi dkk (2014) membuktikan bahwa audit kinerja berpengaruh positif dan signifikan terhadap akuntabilitas publik. Sukmawati dkk (2013) menyatakan bahwa kemampuan mempertanggungjawabkan (akuntabilitas) dari sektor publik pemerintah sangat tergantung pada kualitas audit sektor publik. Tanpa kualitas audit yang baik, maka akan timbul permasalahan, seperti munculnya kecurangan, korupsi, kolusi dan berbagai ketidakberesan di pemerintahan.

Jadi dengan adanya audit kinerja dapat diketahui apakah suatu instansi melaksanakan tugas dan fungsinya secara efisien, efektif dan ekonomis, serta apakah kinerja yang dicapai sesuai dengan kriteria yang telah ditetapkan. Sehingga dengan adanya audit kinerja mendorong terwujudnya akuntabilitas publik yang bebas dari kecurangan atau penyalahgunaan seperti praktik korupsi, kolusi, dan nepotisme dalam pelaksanaan aktivitas dan kegiatan pemerintah yang menunjukkan rendahnya akuntabilitas publik. Dengan demikian dapat diajukan hipotesis penelitian sebagai berikut :

Ha1 : Audit kinerja secara parsial berpengaruh terhadap akuntabilitas publik.

\section{Pengaruh Pengawasan terhadap Akuntabilitas Publik}

Pengawasan Fungsional merupakan Pengawasan yang dilakukan oleh aparat pengawasan fungsional, baik yang berasal dari lingkungan internal pemerintah daerah maupun yang berasal dari lingkungan eksternal pemerintah daerah (Wasistiono, 2010). Pelaksanaan pengawasan fungsional 


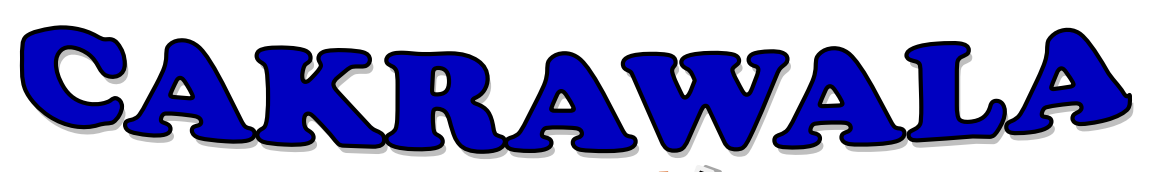

\section{Management Business Journal [CM]-BJ]/olume 2 Nomor 2 November Tahun 2019}

diarahkan terhadap pelaksanaan tugas umum pemerintahan dan pembangunan, dengan tujuan agar pelaksanaan umum pemerintahan dan pembangunan itu berlangsung sesuai dengan rencana dan peraturan perundang-undangan yang berlaku. Supardi dan Sherly (2010) menyatakan bahwa pengawasan fungsional yang akan menunjang akuntabilitas publik. Terwujudnya akuntabilitas merupakan tujuan utama dari reformasi sektor publik. Sehingga dengan dilaksanakannya pengawasan fungsional yang memadai akan menunjang akuntabilitas publik.

Rahayu (2011:151) dalam penelitiannya menyatakan bahwa terdapat pengaruh yang signifikan dari pengawasan fungsional terhadap akuntabilitas publik. Pernyataan tersebut diperkuat dengan penelitian Wulandari (2013) yang membuktikan bahwa pengawasan fungsional berpengaruh terhadap akuntabilitas publik pada pemerintahan Kota Padang. Demikian pula Pamungkas (2012) yang membuktikan bahwa Penerapan akuntansi keuangan sektor publik, pengawasan dan kualitas laporan keuangan pemerintah berpengaruh terhadap akuntabilitas kinerja instansi pemerintah. Darwanis dan Chairunnisa (2013) membuktikan pula bahwa pengawasan kualitas laporan keuangan memiliki korelasi positif dan berpengaruh secara signifikan terhadap akuntabilitas kinerja instansi pemerintah.

Berdasarkan penjelasan diatas dapat diambil kesimpulan bahwa dengan dilakukannya pengawasan oleh aparat pengawasan fungsional maka hal tersebut akan berpengaruh signifikan dalam menunjang akuntabilitas publik, dikarenakan tujuan pelaksanaan umum pemerintahan dan pembangunan berlangsung sesuai dengan rencana dan peraturan perundang-undangan yang berlaku, sehingga dapat dipertanggung-jawabkan terhadap publik. Jika pengawasan fungsional dilaksanakan dengan baik, maka akan tercipta akuntabilitas publik yang baik juga. Dengan demikian dapat diajukan hipotesis penelitian sebagai berikut :

Ha2: Pengawasan secara parsial berpengaruh terhadap akuntabilitas publik.

\section{Pengaruh Audit Kinerja dan Pengawasan Secara Simultan terhadap Akuntabilitas Publik}

Audit pada organisasi sektor publik tidak hanya mencakup audit atas laporan keuangan dan audit dengan tujuan tertentu, namun juga audit kinerja yang merupakan perluasan dari audit tersebut. Menurut UU No.15 Tahun 2004 audit kinerja merupakan pemeriksaan atas pengelolaan keuangan negara yang terdiri atas aspek ekonomi, efisiensi, dan efektivitas.

Audit kinerja menitikberatkan pemeriksaan pada tindakan-tindakan dan kejadian-kejadian ekonomi yang menggambarkan kinerja entitas atau fungsi yang diaudit. Dimana audit kinerja meliputi audit atas aspek ekonomi, efisiensi, dan efektivitas yang merupakan perluasan dari audit atas laporan keuangan dari segi tujuan dan prosedur dalam pelaksaannya (Deddy dan Sherly, 2010 dalam Rahayu, 2011). Penelitian Suratmi dkk (2014) membuktikan bahwa audit kinerja berpengaruh positif dan signifikan terhadap akuntabilitas publik.

Selain itu, pelaksanaan pengawasan fungsional akan menunjang akuntabilitas publik, yang diperkuat dengan teori "Dengan audit kinerja, tingkat akuntabilitas pemerintah dalam proses pengambilan keputusan oleh pihak yang bertanggungjawab akan meningkat, sehingga mendorong pengawasan dan kemudian tindakan koreksi". (IBastian, 2007). Dengan demikian dapat diajukan hipotesis penelitian sebagai berikut : 


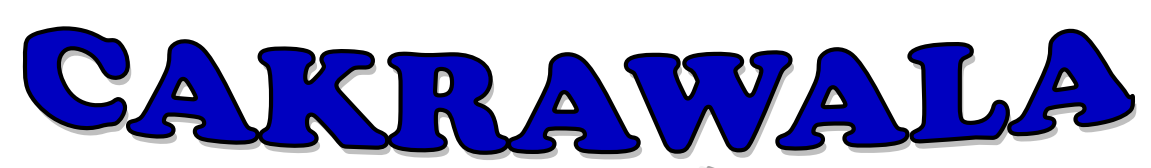

\section{Management Business Journal [CM]-BJ]/olume 2 Nomor 2 November Tahun 2019}

Ha3: Audit kinerja dan pengawasan secara simultan berpengaruh terhadap akuntabilitas publik.

\section{METODE PENELITIAN}

Pendekatan dalam penelitian ini adalah pendekatan deskriptif dan asosiatif, karena adanya variabel-variabel yang akan ditelaah hubungannya serta tujuannya untuk menyajikan gambaran secara terstruktur, faktual, dan akurat mengenai fakta-fakta serta hubungan antar variabel yang diteliti melalui pengujian hipotesis (sugiyono, 2012)

Penelitian ini dilakukan pada Suku Dinas Pendidikan Kota Jakarta Pusat. Populasi sasaran adalah pegawai Suku Dinas Pendidikan Kota Jakarta Pusat yang berjumlah 54 pegawai. Teknik sampel yang dipilih yaitu sampling jenuh (sensus) adalah teknik penentuan sampel bila semua anggota populasi digunakan sebagai sampel. Instrumen penelitian yang digunakan dalam penelitian ini menggunakan kuisioner. Teknik analisis data yang digunakan adalah aplikasi SPSS 20.

Analisis data yang di gunakan adalah uji kualitas data yang terdiri dari uji validitas dan uji reliabilitas. Selanjutnya dilakukan Uji asumsi klasik terdiri dari uji normalitas, uji multikolinieritas, uji heterokedastisitas dan uji autokorelasi. Pengujian hipotesis menggunakan analisis regresi linier berganda. Pengujian hipotesis juga menggunakan uji koefisien determinasi, uji parsial (Uji t), dan uji simultan (uji F).

\section{HASIL PENELITIAN}

Uji validitas untuk masing-masing variabel yang digunakan dalam penelitian ini, dimana keseluruhan variabel penelitian memuat 35 pernyataan, terlihat bahwa dari 35 butir pernyataan yang digunakan untuk mengukur variabel audit kinerja, pengawasan fungsional dan akuntabilitas public, seluruhnya memiliki rhitung $>$ rtabel dan signifikansi $<0,05$ sehingga dinyatakan valid dan dapat dilakukan pengujian pada tahap selanjutnya. Sedangkan hasil pengujian reliabilitas menunjukkan nilai koefisien Alpha dari variabel-variabel yang diteliti menunjukkan hasil yang beragam dan variabel menghasilkan nilai Cronbach Alpha lebih besar dari 0,60. Dengan demikian dapat disimpulkan bahwa alat ukur yang digunakan dalam penelitian ini adalah reliabel.

\section{Uji Asumsi Klasik}

Sebelum data diolah dengan regresi berganda, maka dilakukan uji asumsi klasik untuk memperoleh keyakinan bahwa data yang diperoleh beserta variabel penelitian layak untuk diolah lebih lanjut. Uji asumsi klasik yang dilakukan terdiri atas Uji normalitas bertujuan untuk menguji apakah dalam regresi variabel dependen dan independen memiliki distribusi normal atau mendekati normal. 


\section{CAKrawala}

\section{Management Business Journal [CM:-B] J]/lolume 2 Nomor 2 November Tahun 2019}

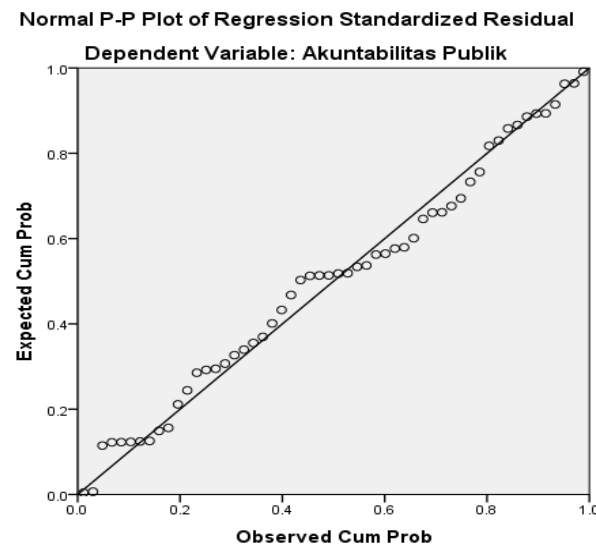

Page | - $333-$

Gambar 2.

Uji Normalitas

Dari hasil perhitungan analisis menggunakan program SPSS, terlihat titik-titik menyebar di sekitar garis diagonal. Hal ini menunjukkan bahwa data yang ada layak untuk dipakai dalam model regresi karena memenuhi asumsi normalitas. Selanjutnya dilakukan Uji Heteroskedastisitas bertujuan menguji apakah dalam model regresi terjadi kesamaan atau ketidaksamaan variance.

Scatterplot

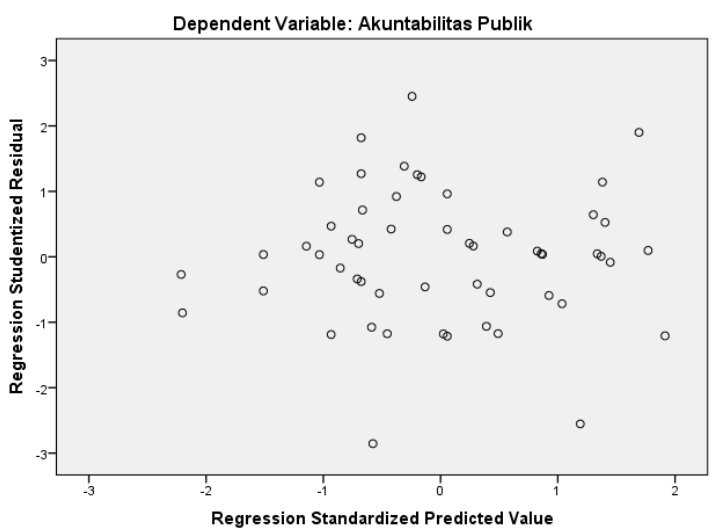

Gambar 3.

Uji Heteroskedastisitas

Dari hasil perhitungan menggunakan SPSS dari diagram tersebut menunjukkan bahwa titik-titik (yang menggambarkan data) menyebar secara acak, tidak membentuk pola tertentu yang jelas, serta tersebar baik di atas maupun di bawah angka 0 pada sumbu Y. Hal ini berarti tidak terjadi heteroskedastisitas pada model regresi, sehingga model regresi layak dipakai.

\section{Uji Multikolinearitas}

Hasil uji multikolonieritas menunjukkan bahwa model regresi tidak mengalami gangguan multikolonieritas. Hal ini tampak pada nilai tolerance masing-masing variabel bebas yang lebih besar 


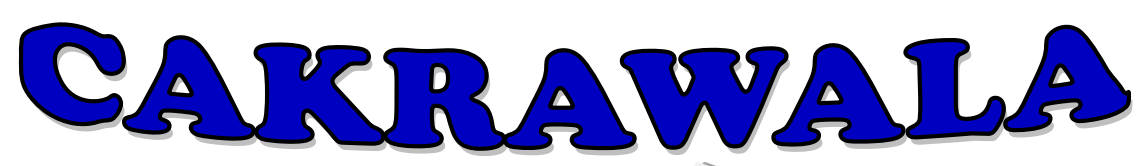

\section{Management Business Journal [CM]-BJ]/olume 2 Nomor 2 November Tahun 2019}

dari 0,1. Hasil penghitungan VIF juga menunjukan bahwa nilai VIF masing-masing variabel bebas kurang dari 10. Jadi dapat disimpulkan bahwa tidak ada multikolonieritas antar variabel bebas dalam model regresi.

\section{Uji Autokorelasi}

Pada uji ini dapat dilihat pada tabel Model Summary nilai DW-nya menunjukkan nilai 1,802, sehingga didapatkan persamaan autokorelasi sebagai berikut : $d u<d<4$-du yaitu 1,638 $<1,802<2,362$. Dengan demikian dapat diputuskan tidak terjadi autokorelasi positif atau negatif, atau model regresi memenuhi persyaratan asumsi klasik tentang autokorelasi.

\section{Tabel 1.}

Hasil Regresi Linear Berganda

\begin{tabular}{|c|c|c|c|c|c|c|}
\hline \multicolumn{2}{|c|}{ Model } & \multicolumn{2}{|c|}{ Unstandardized Coefficients } & \multirow{2}{*}{$\begin{array}{l}\text { Standardized } \\
\text { Coefficients } \\
\text { Beta }\end{array}$} & \multirow[t]{2}{*}{$\mathrm{t}$} & \multirow[t]{2}{*}{ Sig. } \\
\hline & & B & Std. Error & & & \\
\hline \multirow[t]{9}{*}{1} & (Constant) & 10.666 & 3.523 & & 3.027 & .004 \\
\hline & Audit Kinerja & .304 & .075 & .496 & 4.028 & .000 \\
\hline & Pengawasan & .234 & .088 & .328 & 2.660 & .010 \\
\hline & Fungsional & & & & & \\
\hline & $\mathrm{R}$ & $.755 a$ & & & & \\
\hline & R Square & .571 & & & & \\
\hline & Adjusted R Square & .554 & & & & \\
\hline & Fhitung & 33,910 & & & & \\
\hline & Signifikansi F & 0,000 & & & & \\
\hline
\end{tabular}

Model persamaan regresi yang dapat dituliskan dari hasil tersebut dalam bentuk persamaan regresi bentuk standard adalah sebagai berikut :

$\mathrm{Y}=10,666+0,304 \mathrm{X} 1+0,234 \mathrm{X} 2+\mathrm{e}$

Persamaan regresi tersebut dapat dijelaskan sebagai berikut :

1) Nilai B constant sebesar 10,666 menyatakan bahwa, apabila variabel audit kinerja dan pengawasan fungsional diasumsikan konstan atau 0 , maka akuntabilitas publik adalah sebesar 10,666 satuan.

2) Nilai koefisien regresi variabel audit kinerja sebesar 0,304 bernilai positif mempunyai arti bahwa jika audit kinerja naik sebesar satu satuan, maka akuntabilitas publik akan meningkat sebesar 0,304 satuan.

3) Nilai koefisien regresi variabel pengawasan fungsional sebesar 0,234 bernilai positif mempunyai arti bahwa jika pengawasan fungsional naik sebesar satu satuan, maka akuntabilitas publik akan meningkat sebesar 0,234 satuan.

Hasil uji - F sebesar 33,910 > Ftabel 3,18 dengan sig. 0,000. Nilai sig. uji - F yang lebih kecil (<) dari $\alpha$ $=0,05$ menunjukkan diterimanya hipotesis yang menyatakan secara simultan terdapat pengaruh yang signifikan dari variabel audit kinerja dan pengawasan fungsional terhadap akuntabilitas publik. 


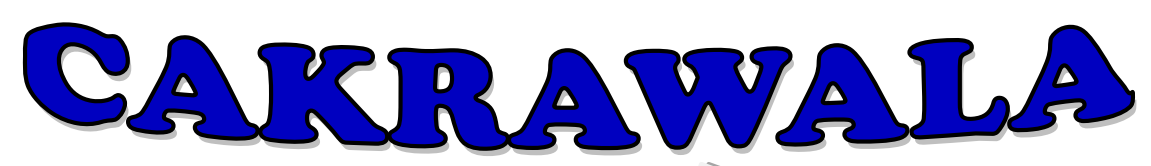

\section{Management Business Journal [CM:-B]J/lolume 2 Nomor 2 November Tahun 2019}

Persamaan regresi menunjukan nilai adjusted R2 sebesar 0.554 atau 55,4\%. Hal tersebut berarti $55,4 \%$ perubahan akuntabilitas publik dipengaruhi oleh audit kinerja dan pengawasan fungsional. Sementara $44.6 \%$ akuntabilitas publik dijelaskan oleh faktor-faktor lain diluar audit kinerja dan pengawasan fungsional.

\section{PEMBAHASAN}

\section{Pengaruh audit kinerja sektor publik terhadap akuntabilitas publik}

Berdasarkan analisis statistik dalam penelitian ini diperoleh nilai koefisien regresi audit kinerja sebesar 0,304. Hal ini menunjukkan bahwa audit kinerja berpengaruh positif terhadap akuntabilitas publik. Nilai signifikan audit kinerja sebesar $0,000<0,05$. Hal ini menunjukkan bahwa audit kinerja berpengaruh signifikan terhadap akuntabilitas publik. Dengan demikian hipotesis pertama $(\mathrm{H} 1)$ diterima yang menyatakan audit kinerja berpengaruh positif dan signifikan terhadap akuntabilitas publik. Hal ini berarti semakin baik audit kinerja, maka akan terjadi peningkatan akuntabilitas publik pada Suku Dinas Pendidikan Kota Jakarta Pusat.

Hasil penelitian ini sejalan dengan penelitian yang dilakukan oleh Rahayu (2011), Kristianto (2011), suratmi dkk (2014) yang menemukan bahwa audit kinerja memiliki pengaruh yang signifikan dan positif terhadap akuntabilitas publik. Apabila pelaksanaan audit kinerja dilakukan dengan baik, maka tingkat akuntabilitas pemerintah dalam proses pengambilan keputusan oleh pihak yang bertanggungjawab akan meningkat, sehingga mendorong adanya pengawasan dan kemudian tindakan koreksi.

Berkaitan dengan audit kinerja, inspektorat yang merupakan auditor internal pemerintah bertanggung jawab dalam pelaksanaan audit kinerja. Dimana dengan dilakukannya audit kinerja, auditor melakukan proses audit untuk memperoleh dan mengevaluasi bukti untuk melakukan penilaian secara independen atas aspek ekonomi, efisiensi, dan efektifitas dari kegiatan yang dilakukan pemerintah. Dalam hal ini apakah pemerintah dalam melaksanakan kegiatan sesuai dengan peraturan, hukum, dan kebijakan yang berlaku, dan apakah terdapat kesesuaian antara kinerja yang dicapai dengan kriteria yang telah ditetapkan. Dengan demikian audit kinerja ditujukan agar penyelenggaraan tugas dan fungsi organisasi dalam rangka memberikan keyakinan yang memadai bahwa kegiatan telah dilakukan sesuai dengan acuan yang telah ditetapkan sebagai wujud pertanggungjawaban kepada pihak-pihak yang berkepentingan.

Jadi dengan adanya audit kinerja dapat diketahui apakah suatu instansi melaksanakan tugas dan fungsinya secara efisien, efektif dan ekonomis, serta apakah kinerja yang dicapai sesuai dengan kriteria yang telah ditetapkan. Sehingga dengan adanya audit kinerja mendorong terwujudnya akuntabilitas publik yang bebas dari kecurangan atau penyalahgunaan seperti praktik korupsi, kolusi, dan nepotisme dalam pelaksanaan aktivitas dan kegiatan pemerintah yang menunjukkan rendahnya akuntabilitas publik.

\section{Pengaruh pengawasan fungsional terhadap akuntabilitas publik}

Berdasarkan analisis statistik dalam penelitian ini diperoleh nilai koefisien regresi pengawasan fungsional sebesar 0,234. Hal ini menunjukkan bahwa pengawasan fungsional berpengaruh positif 


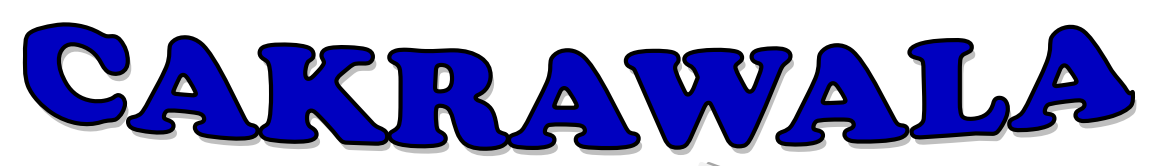

\section{Management Business Journal [CM]-BJ]/olume 2 Nomor 2 November Tahun 2019}

terhadap akuntabilitas publik. Nilai signifikan pengawasan fungsional sebesar 0,010 $<0,05$. Hal ini menunjukkan bahwa pengawasan fungsional berpengaruh signifikan terhadap akuntabilitas publik. Dengan demikian hipotesis kedua $(\mathrm{H} 2)$ diterima yang menyatakan pengawasan fungsional berpengaruh positif dan signifikan terhadap akuntabilitas publik. Hal ini berarti semakin baik pengawasan fungsional, maka akan terjadi peningkatan akuntabilitas publik.

Hasil penelitian ini konsisten dengan penelitian yang dilakukan oleh Rahayu (2011), Pamungkas (2012) yang menemukan bahwa pengawasan fungsional memiliki pengaruh yang signifikan dan positif dalam mewujudkan akuntabilitas publik. Hal ini dikarenakan tujuan pelaksanaan umum pemerintahan dan pembangunan berlangsung sesuai dengan rencana dan peraturan perundang-undangan yang berlaku, sehingga dapat dipertanggungjawabkan terhadap publik. Jika pengawasan fungsional dilaksanakan dengan baik, maka akan tercipta akuntabilitas publik yang baik juga.

Berkaitan dengan pengawasan fungsional, Inspektorat sebagai salah satu aparat pengawas fungsional memiliki peran penting dalam melaksanakan pengawasan. Berdasarkan PP No.60 tahun 2008, inspektorat daerah melakukan pengawasan fungsional intern yaitu seluruh kegiatan audit, review, evaluasi pemantauan, dan kegiatan pengawasan lain terhadap penyelenggaraan tugas dan fungsi organisasi dalam rangka memberikan keyakinan yang memadai bahwa kegiatan telah dilaksanakan sesuai dengan tolak ukur yang telah ditetapkan secara efektif dan efisien untuk kepentingan pimpinan dalam mewujudkan pertanggungjawabannya.

Jadi dengan adanya pengawasan fungsional dapat diketahui apakah suatu instansi pemerintah khususnya dalam hal ini adalah Suku Dinas Pendidikan Kota Jakarta Pusat telah melaksanakan kegiatan sesuai dengan tugas dan fungsinya secara efektif dan efisien, serta sesuai dengan rencana, kebijakan yang telah ditetapkan. Sehingga dengan adanya pengawasan fungsional oleh inspektorat daerah pada khususnya dapat mendorong terwujudnya akuntabilitas publik yang bebas dari praktik korupsi, kolusi, dan nepotisme.

\section{Pengaruh audit kinerja sektor publik dan pengawasan fungsional secara simultan terhadap akuntabilitas publik}

Berdasarkan hasil pengujian hipotesis diperoleh nilai signifikansi pada uji anova sebesar 0,000 $<0,05$, hal ini berarti hipotesis yang menyatakan terdapat pengaruh yang positif dan signifikan dari audit kinerja dan pengawasan fungsional secara simultan terhadap akuntabilitas publik (H3) diterima. Dengan kata lain dapat disimpulkan bahwa terdapat pengaruh audit kinerja dan pengawasan fungsional secara bersama-sama terhadap akuntabilitas publik. Besarnya pengaruh audit kinerja sektor publik dan pengawasan fungsional terhadap akuntabilitas publik adalah sebesar $55,4 \%$. Artinya 55,4\% perubahan akuntabilitas publik pada Suku Dinas Pemerintah Kota Jakarta Pusat dapat dijelaskan oleh variabel audit kinerja sektor publik dan pengawasan fungsional, sedangkan sisanya sebesar $44,6 \%$ dipengaruhi faktor lain seperti pelayanan publik, kualitas informasi keuangan, dan manajerial. (Deddy dan Sherly, 2010)

Bastian (2010:48) menyatakan bahwa apabila pelaksanaan audit kinerja dilakukan dengan baik, maka tingkat akuntabilitas pemerintah dalam proses pengambilan keputusan oleh pihak yang 


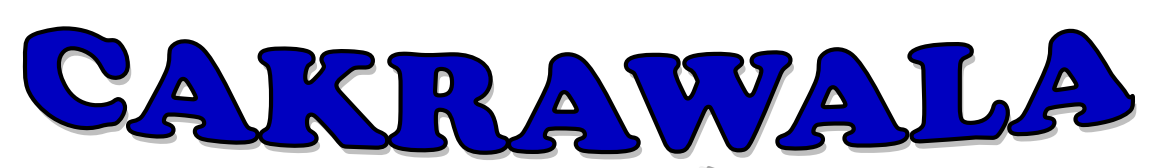

\section{Management Business Journal [CM]-BJ]/olume 2 Nomor 2 November Tahun 2019}

bertanggungjawab akan meningkat, sehingga mendorong adanya pengawasan dan kemudian tindakan koreksi. Demikian pula Rai (2010:46) menyatakan bahwa audit yang dilakuakan secara objektif dan sistematis terhadap berbagai macam bukti untuk menilai kinerja entitas yang di audit dalam hal ekonomi, efisiensi, dan efektivitas dengan tujuan untuk memperbaiki kinerja dan entitas yang diaudit dan meningkatkan akuntabilitas publik.

Hal ini menunjukkan bahwa audit kinerja sangatlah penting dalam suatu organisasi atau perusahaan. Suatu organisasi atau perusahaan dapat dinilai ketika administrasi dan penyediaan jasa oleh perusahaan yang bersangkutan dilakukan pada tingkat yang ekonomis, efesiensi dan efektif. Audit kinerja dan akuntabilitas publik Suku Dinas Pendidikan Kota Jakarta Pusat sudah terpenuhi dengan baik, hal ini didukung telah dilaksanakannya audit dalam hal ekonomi, efesiensi dan efektivitas. Akuntabilitas merupakan kewajiban-kewajiban dari individu atau penguasa yang dipercayakan untuk mengelola sumberdaya publik dan yang bersangkutan dengannya untuk dapat menjawab hal-hal yang menyangkut pertanggungjawaban kepada publik. Maka untuk mempertanggungjawabkan kepada publik maka dibutuhkan suatu pengawasan terhadap pengelolaan keuangan suku dinas tersebut.

Pelaksanaan pengawasan fungsional diarahkan terhadap pelaksanaan tugas umum pemerintahan dan pembangunan, dengan tujuan agar pelaksanaan umum pemerintahan dan pembangunan itu berlangsung sesuai dengan rencana dan peraturan perundang-undangan yang berlaku. pengawasan fungsional akan menunjang akuntabilitas publik. Terwujudnya akuntabilitas merupakan tujuan utama dari reformasi sektor publik. Sehingga dengan dilaksanakannya pengawasan fungsional yang memadai akan menunjang akuntabilitas publik. Terwujudnya akuntabilitas merupakan tujuan utama dari reformasi sektor publik. Dengan pengawasan fungsional yang memadai akan menunjang akuntabilitas pengelolaan keuangan Suku Dinas Pendidikan Pemerintah Kota Jakarta Pusat.

\section{KESIMPULAN}

Berdasarkan hasil penelitian dan pembahasan pada bab sebelumnya, maka dapat disampaikan beberapa kesimpulan penelitian bahwa Hasil uji hipotesis secara parsial disimpulkan bahwa audit kinerja berpengaruh positif dan signifikan terhadap akuntabilitas publik. Hal ini berarti apabila audit kinerja semakin baik maka akuntabilitas publik akan semakin meningkat pula.

Hasil uji hipotesis secara parsial disimpulkan bahwa pengawasan fungsional berpengaruh positif dan signifikan terhadap akuntabilitas publik. Hal ini berarti apabila pengawasan fungsional semakin meningkat maka akan dapat meningkatkan akuntabilitas publik. Hasil uji hipotesis secara simultan disimpulkan bahwa audit kinerja dan pengawasan fungsional berpengaruh positif dan signifikan terhadap akuntabilitas publik.

Hal ini berarti apabila audit kinerja dan pengawasan fungsional dilakukan secara bersamasama semakin meningkat maka akuntabilitas publik pada Suku Dinas Pendidikan Kota Jakarta Pusat akan semakin meningkat pula. 


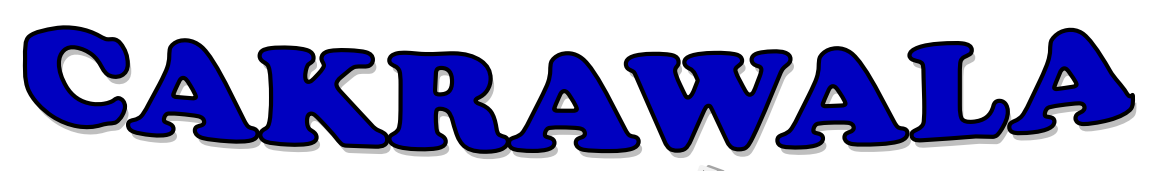

\section{Management Business Journal [CM:-BJ]/olume 2 Nomor 2 November Tahun 2019}

\section{REKOMENDASI}

Beberapa rekomendasi bagi Suku Dinas Pendidikan Kota Jakarta Pusat sebaiknya tidak hanya terbatas pada rekomendasi yang diberikan oleh auditor atas hasil audit kinerja tapi pelaksanaan dari tindak lanjut audit tersebut yang sangat penting terlebih lagi dari segi ekonomi dan efisiensi serta kepatuhan terhadap kebijakan, dan peraturan hukum yang berlaku, dalam hal kinerja pemerintah khususnya bendahara yang masih dikategorikan cukup, dimana diharapkan dapat memberikan kontribusi bagi perbaikan kegiatan selanjutnya, sehingga kinerja pada periode berikutnya bisa lebih baik.

Kepada pihak yang terkait dengan pengawasan fungsional pada Suku Dinas Pendidikan Kota Jakarta Pusat agar lebih meningkatkan kinerja dalam segi pengawasan fungsional yang dimaksudkan untuk mencegah tumbuhnya berbagai macam bentuk penyimpangan dari pelaksanaan anggaran sehingga pelaksanaan pengawasan fungsional yang telah terlaksana dapat lebih baik lagi dimasa yang akan datang.

Untuk akuntabilitas publik agar dapat terlaksana dengan baik, maka harus lebih terbuka dalam hal laporan pertanggungjawaban program-program yang terlaksana kepada masyarakat yaitu melalui perwakilan publik. Selain itu masukan dan keluhan yang berasal dari masyarakat dapat menjadi feedback dalam perbaikan kinerja pada periode berikutnya.

\section{DAFTAR REFERENSI}

Ardiansyah Andhika. 2010. Pengaruh Pengawasan Fungsional Terhadap Kinerja Pemerintah Daerah (Studi pada Inspektorat Provinsi Jawa Barat). E-Jurnal: FE-Universitas Pasundan. . Bandung

Arfianto Dheny Ayudya, 2010. Studi Perbandingan Audit Kinerja Pada Badan Pemeriksa Keuangan Dengan Lembaga Pemeriksa Keuangan Negara Lain. Tesis. Depok : FE UI.

Bastian, Indra. 2010. Audit Sektor Publik. Jakarta : Salemba Empat.

Darwanis dan Chairunnisa Sephi. 2013. Akuntabilitas Kinerja Instansi Pemerintah. Jurnal Telaah \& Riset Akuntansi. Vol. 6 No. 2 Juli 2013. HIm. 150-174.

Ghozali, Imam.2011. Aplikasi Analisis Multivariate dengan Program SPSS. Semarang : Badan Penerbit UNDIP.

Instruksi Presiden Republik Indonesia No. 15 Tahun 1983 tentang Pedoman Pelaksanaan Pengawasan Pasal 1.

Keputusan BPKP No. KEP-378/K/2004 tanggal 30 Mei 2004 Tentang Penetapan Berlakunya Standar Audit Aparat Pengawasan Fungsional Pemerintah.

Kristianto, Yudi. 2011. Pengaruh Aksesibilitas Laporan Keuangan dan Audit Kinerja terhadap Akuntabilitas Publik (Studi pada Pemerintah Kota Bandung). Skripsi. Universitas Komputer Indonesia, Bandung.

Nordiawan Deddi dan Hertianti Ayuningtyas. 2010. Akuntansi Sektor Publik. Edisi 2. Jakarta : Penerbit Salemba Empat.

Pamungkas Bambang. 2012. Pengaruh Penerapan Akuntansi Sektor Publik dan Pengawasan Terhadap Kualitas Laporan Keuangan dan Implikasinya Terhadap Akuntabilitas Kinerja Instansi Pemerintah. Jurnal Ilmiah Ranggagading. Volume 12 No. 2, Oktober 2012:82-93. 


\section{Carcrawala}

Peraturan Pemerintah No. 79 Tahun 2005 Pasal 1 tentang Pedoman Pembinaan dan Pengawasan Penyelenggaraan Pemerintahan Daerah.

Rahayu, Cici. 2011. Pengaruh Audit kinerja Sektor Publik dan Pengawasan fungsional terhadap Akuntabilitas Publik. Skripsi. UNIKOM. Bandung.

Ritonga Rahmansyah. 2013. Optimalisasi audit kinerja Instansi pemerintah. http://sumut.kemenag.go.id.

Rai, I Gusti Agung. 2010. Audit Kinerja Sektor Publik. Jakarta : Salemba Empat.

Renyowijoyo Muindro, 2013. Akuntansi Sektor Publik Organisasi Non Laba. Edisi 3. Jakarta : Penerbit Mitra Wacana Media.

Sukmawati Aegisia dkk. 2013. Audit Kinerja Pada Sektor Publik. Makalah. Fakultas Ekonomi Universitas Jambi.

Sugiyono. 2012. Metode Penelitian Bisnis. Bandung : CV Alfabeta.

Supardi Deddy, Wiarty Sheirly. 2010. Peranan Audit Kinerja dalam Akuntabilitas. Jurnal UNIKOM. Vol. I, No. 2. April. HIm. 77-94.

Suratmi, Heriawati dan Darmawan, 2014. Pengaruh Audit Kinerja, Penyajian Laporan Keuangan dan Aksesibilitas Laporan Keuangan Terhadap Akuntabilitas Publik. Jurnal Akuntansi. Program S1, Volume 2 No. 1 Tahun 2014. E-Journal S1 Ak Universitas Pendidikan Ganesha.

Wasistiono, Sadu.2010. Pengelolaan Keuangan Dan aset Daerah. Bandung : Fokusmedia. 